\title{
Correction to: The impact of different land uses in urban area on humus quality
}

\author{
Lidia Oktaba $^{1} \cdot$ Diana Odrobińska $^{1} \cdot$ Łukasz Uzarowicz $^{1}$
}

Published online: 30 August 2018

(C) The Author(s) 2018

\section{Correction to: Journal of Soils and Sediments (2018) 18:2823-2832 https://doi.org/10.1007/s11368-018-1982-7}

The article "The impact of different land uses in urban area on humus quality", written by Lidia Oktaba, Diana Odrobińska, and Łukasz Uzarowicz was originally published electronically on 7 April 2018 with incorrect copyright line in the publisher's internet portal (currently SpringerLink). The copyright line of the article should be "C) The Author(s) 2018".

Open Access This article is distributed under the terms of the Creative Commons Attribution 4.0 International License (http:// creativecommons.org/licenses/by/4.0/), which permits unrestricted use, distribution, and reproduction in any medium, provided you give appropriate credit to the original author(s) and the source, provide a link to the Creative Commons license, and indicate if changes were made.

The online version of the original article can be found at https://doi.org/ 10.1007/s11368-018-1982-7

Lidia Oktaba

lidia_oktaba@sggw.pl

1 Department of Soil Environment Sciences, Warsaw University of Life Science-SGGW, Nowoursynowska 159,

02-776 Warsaw, Poland 